MATEC Web of Conferences 22,05020 (2015)

DOI: $10.1051 /$ matec conf/ 20152205020

(C) Owned by the authors, published by EDP Sciences, 2015

\title{
A Study and Application of Biocatalytic Synthesis of (S)-N-Boc-3-hydroxypiperidine
}

\author{
Ying Chen \& Yi Xu* \\ School of Chemical and Environmental Engineering, Shanghai Institute of Technology, Shanghai, China \\ Jianbo Chen \\ College of Life and Environment Science, Shanghai Normal University, Shanghai, China
}

\begin{abstract}
This paper first uses the environmental friendly whole cell of biocatalyst pichia pastoris SIT2014 to asymmetrically synthesized anti-tumor drug of chiral intermediate (S)-N-Boc-3-hydroxypiperidine.. Improve the final biocatalytic reduction yield to $85.4 \%$ based on the study of fermentation optimization and biocatalytic asymmetrical reduction system for pichia pastoris. The ee value of obtained reduction product (S)-N-Boc-3-hydroxypiperidine hits over $99 \%$. The study of this article is a successful case where the biocatalyst is applied to the green synthesis of chiral intermediate of anti-tumor drug.
\end{abstract}

Keywords: pichia pastoris; biocatalyst; (S)-N-Boc-3-hydroxypiperidine; asymmetrical reduction

\section{INTRODUCTION}

Piperidines derivative has many pharmacological activities, such as anti-biosis, anti-tumor, senile dementia treatment and anesthesia. N-Boc-3-pipradrol is an important intermediate ${ }^{1-2}$ of anti-tumor drug with important study value. Currently, there are few reports about the synthesis research on N-Boc-piperidines or other similar matters, neither in China. It is reported from foreign literatures that the synthesis of minor relevant similar drugs, such as N-Boc-piperidines-3-acetic acid, is conducted by high-temperature catalytic hydrogenation by pyridine-3-acetic acid under protection of Boc. The advantage of this synthesis method is that it contains less steps and requires just high-pressure reduction condition. It has several disadvantages, for example, it has a very high requirement on the devices, and its raw material costs much and is hard to be synthesized ${ }^{3-4}$. What mentioned above indicates in the study of compound of the same kind, many methods have demanding conditions and their values are hard to be realized. Whereas, the biocatalyst has many features $^{5}$, such as modest reaction condition, high catalytic efficiency, high selectivity and low pollution. It has many wide and important usages in drug synthesis $^{6-8}$. The biocatalyst synthesis refers to the process of using organism, such as cell or cell organ, and taking enzyme as the catalyst to realize chemical conversion. While the process of using pure enzyme or organism to catalyze achiral or prochiral compound to be converted to chiral product is referred to as chiral synthesis of biocatalyst. The biocatalyst has the advantages of modest reaction condition and high catalytic efficiency. Most importantly, it complies with the current requirement of green chemistry ${ }^{9-11}$. It has a wide prospect of development and application.

The process of using carbonyl reductase in microbial cell to catalyze the substrate N-Boc-3-piperidone asymmetrical reduction to obtain the chiral N-Boc-3-piperidrol has many advantages, such as modest reaction condition, low pollution and economic process, and it is a green and environmental-friendly synthesis route with much competitiveness. This article first conducts a series of research on the selection and cultivation of biocatalyst to screen out the biocatalyst suitable for this asymmetrical reduction, and study the enzymatic reduction of N-Boc-3-piperidone by biocatalyst .

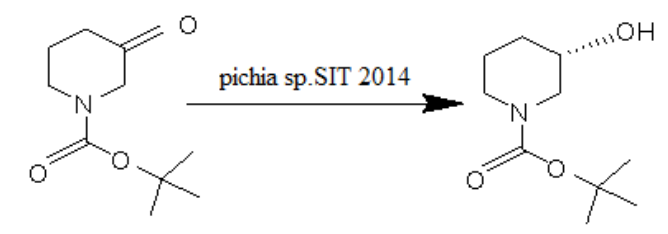

Figure1. Biocatalytic asymmetric synthesis of (S) -N-Boc-3-hydroxypiperidine

\section{EXPERIMENTAL REAGENT AND ANALYSIS METHOD}

Experimental reagent: glucose, peptone, yeast powder $\mathrm{KH}_{2} \mathrm{PO}_{4}, \mathrm{NaCl}, \mathrm{MgSO}_{4} \cdot 7 \mathrm{H}_{2} \mathrm{O}$, anhydrous sodium sulfate, ethanol, ethyl acetate, phosphate buffer solution, N-Boc-3-piperidones and (S)-N-Boc-3-piperidrol.

*Corresponding author: xuyi@sit.edu.cn

This is an Open Access article distributed under the terms of the Creative Commons Attribution License 4.0, which permits unrestricted use, distribution, and reproduction in any medium, provided the original work is properly cited. 


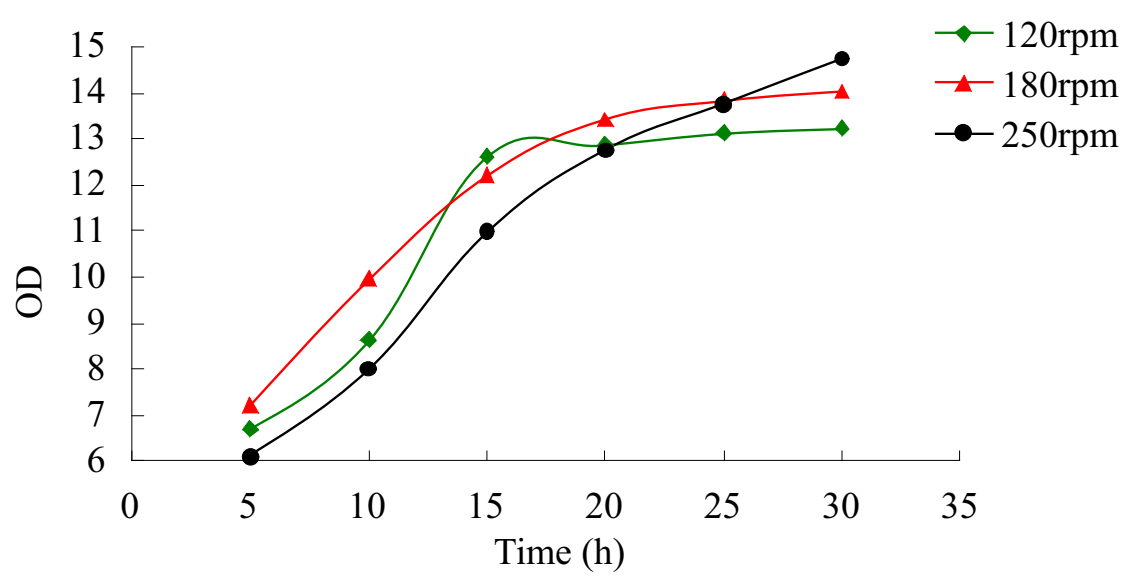

Figure 2. The growing curves of Pichia sp. in different shaking speed of shaker.

Analysis method: analysis on biological reduction yield by chiral gas chromatographic column.

Brand of column: RS-Supelco.

Model of column: Beta DEXTM 120 Capillary Column.

Specification of column: $30 \mathrm{~m} * 0.25 \mathrm{~mm} * 0.25 \mathrm{um}$ film thickness.

Analysis condition: the product reaction solution from reduction is extracted by ethyl acetate, and analyzed by gas chromatographic column after being dried, with sample size of lul.

The temperature of injector and detector is set as respectively $130{ }^{\circ} \mathrm{C}$ and $180^{\circ} \mathrm{C}$.

The initial column temperature is $100{ }^{\circ} \mathrm{C}$, which will be increased to $160{ }^{\circ} \mathrm{C}$ by temperature programming. The steps of temperature programming are set as increasing to $130{ }^{\circ} \mathrm{C}$ as per $5{ }^{\circ} \mathrm{C}$ increment per minute within $100{ }^{\circ} \mathrm{C}$; keeping this temperature for 2 minutes and increasing to $160{ }^{\circ} \mathrm{C}$ as per $2{ }^{\circ} \mathrm{C}$ increment per minute and keeping this temperature for 2 minutes before it comes to an end. The N-Boc-3-piperidone (Boc-ketone for short) is kept in the gas chromatographic for 28.883 minutes, and (S)-N-Boc-3-piperidrol (S-Boc alcohol) is kept for 30.936 minutes.

Analysis of ee value by chiral liquid chromatographic: the product reaction solution from reduction is extracted and dried by ethyl acetate, and subject to liquid chromatographic analysis using isopropanol solvent sample, with sample size of $5 \mathrm{ul}$.

The mobile phase is n-hexane: isopropanol $=97: 3$, flow rate $0.8 \mathrm{ml} / \mathrm{min}$; the detection wavelength is 210 $\mathrm{nm}$; the temperature of column temperature phase is set as $27^{\circ} \mathrm{C}$; chiral OD-H column $4.6 \mathrm{~mm} \times 250 \mathrm{mml}$; the detection time is 20 minutes. The method to calculate ee value of optical purity is as follows:

ee $(\%)=[\mathrm{S}$ (configuration) $-\mathrm{R}($ configuration $) / \mathrm{S}$ (configuration $)+\mathrm{R}($ configuration $)] \times 100 \%$

$\mathrm{S}$ (configuration): represents the peak area of $\mathrm{S}$ (configuration) detected in chiral liquid column

$\mathrm{R}$ (configuration): represents the peak area of $\mathrm{R}$ (configuration) detected in chiral liquid column
The obtained S-Boc alcohol is kept for 12.960 minutes; R-Boc alcohol for 13.861 minutes; Boc-ketone for 10.520 minutes.

\section{OPTIMIZED SELECTION OF BIOCATALYST}

As a catalyst, the microbe has many features such as simple cultivation and high accessibility. The yeast cell is a common microbe that takes itself as a catalytic precursor ketone to be reduced to chiral alcohol. A detailed fermentation optimization research on table turning speed, fermentation time and fermentation liquid $\mathrm{pH}$ for pichia pastoris kept in this laboratory in order to obtain a biocatalyst with high yield and efficiency. Main contents of culture media: glucose: $15(\mathrm{~g} / \mathrm{l})$; peptone: $5(\mathrm{~g} / \mathrm{l})$; yeast powder: $5(\mathrm{~g} / \mathrm{l}) ; \mathrm{K}_{2} \mathrm{HPO}_{4}$ : 0.5(g/l); KH2PO4: $\left.0.5(\mathrm{~g} / \mathrm{l}) ;\right) \mathrm{NaCl}$ : $1(\mathrm{~g} / \mathrm{l}) ; \mathrm{MgSO}_{4} \cdot 7 \mathrm{H}_{2} \mathrm{O}: 0.5(\mathrm{~g} / \mathrm{l})$; the fermentation culture media is the same as seed culture media.

\subsection{Effect of table turning speed on cell growth}

Set the table turning speed as $120 \mathrm{rpm}, 180 \mathrm{rpm}$ and $250 \mathrm{rpm}$, and study the table turning speed most suitable for Aiqieer pichia cell with other cultivation conditions unchanged. The obtained relationship between table turning speed and cell growth is as shown in Figure 2.

It is known from the figure above that, the cell has a fastest fermentation and this process is completed within $18 \mathrm{~h}$ as the turning speed is $120 \mathrm{rpm}$, but the obtained concentration of the cell is not high. Whereas, as the turning speed hits $250 \mathrm{rpm}$, the obtained concentration of the cell reaches the highest level, but it has a slowest fermentation which will be completed in more than $30 \mathrm{~h}$. So $180 \mathrm{rpm}$ of turning speed is selected as the most proper turning speed in consideration of the balance of two affecting factors, that is, fermentation time and the concentration of cell. 


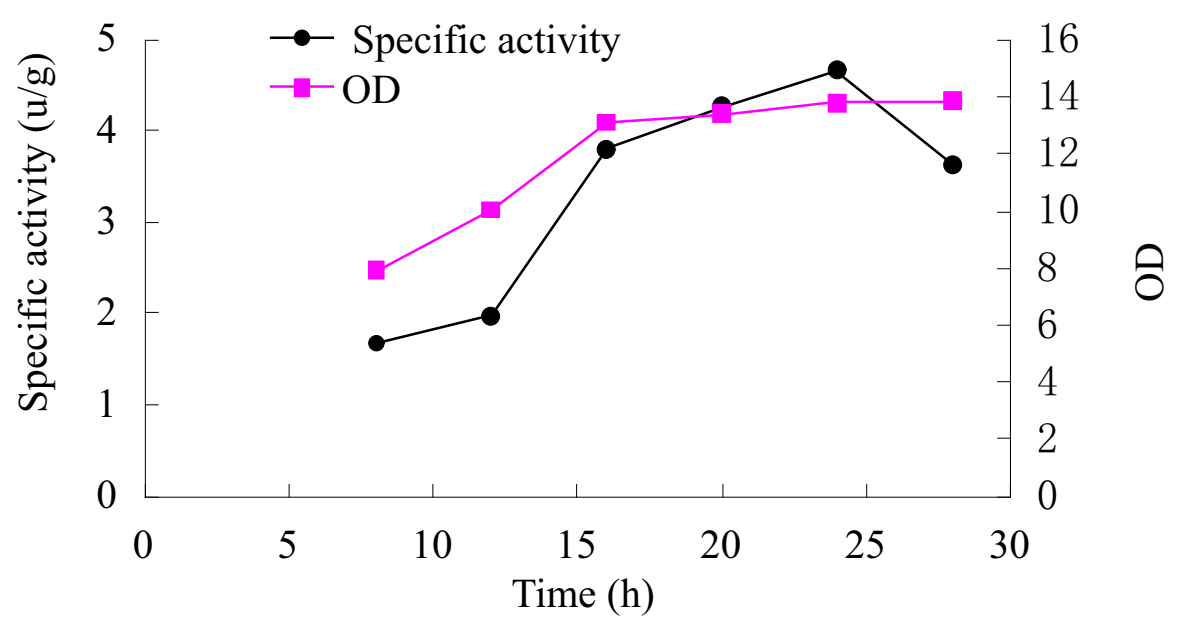

Figure 3. The optimization of fermentation time on Pichia pastoris cell

\subsection{Effect of fermentation time on cell growth}

As shown in the following Figure 3, with the increase of fermentation time, the growth of cell successively comes into logarithmic growth phase and balance phase. After $20 \mathrm{~h}$ of fermentation time, the cell starts to gradually stop its growth. Whereas, it is known from measuring the specific enzyme activity of cell in this period that its specific enzyme activity tends to increase and then decrease. As the fermentation time reaches $24 \mathrm{~h}$, the enzyme activity hits the maximum value of $4.67 \mathrm{U} / \mathrm{g}$. Therefore, it is summarized from the figure above that the optimal time for cultivation and fermentation of pichia pastoris cell is $24 \mathrm{~h}$.

\subsection{Effect of $p H$ value of fermentation liquid on cell growth}

The content of the seed culture media is the same as that of fermentation culture media in the cultivation process of the whole cell. After preparing the culture media, we use $\mathrm{NaOH}$ solution or concentrated phosphoric acid solution to adjust $\mathrm{pH}$ value to a specific level to ferment and cultivate the cell. After cultivation and centrifugal washing, the OD value of cell will be checked in ultraviolet spectrophotometer with its wave length of $600 \mathrm{~nm}$. As shown in Figure 4, the growth of pichia pastoris in an environment with $\mathrm{pH}$ value between 4.5 and 7.0 tends to increase and then decrease. As shown in the data of Figure 4, the cell is suitable to grow in a culture media with fair acidity. OD value of the cell will be increased as $\mathrm{pH}$ value changes from 4.5 to 6.5 ; it will have the best condition of growth as $\mathrm{pH}$ at 6.5 ; while $\mathrm{OD}$ value will decline if $\mathrm{pH}$ continues to grow, which is harmful to the growth of cell.

Finally, determine the cultivation condition by optimizing the cultivation condition of biocatalyst. It is conducted as follows:

Contents of culture media: glucose: $15(\mathrm{~g} / \mathrm{l})$; peptone: $5(\mathrm{~g} / \mathrm{l})$; yeast powder: $5(\mathrm{~g} / \mathrm{l}) ; \mathrm{K}_{2} \mathrm{HPO}_{4}: 0.5(\mathrm{~g} / \mathrm{l})$; $\mathrm{KH}_{2} \mathrm{PO}_{4}: 0.5(\mathrm{~g} / \mathrm{l}) ; \mathrm{NaCl}: 1(\mathrm{~g} / \mathrm{l}) ; \quad \mathrm{MgSO}_{4} \cdot 7 \mathrm{H}_{2} \mathrm{O}$ : $0.5(\mathrm{~g} / \mathrm{l})$.

Adjust $\mathrm{pH}$ value to 6.5 , and the seed culture media is the same as fermentation culture media. The pichia pastoris cell is taken to seed liquid by picking single colony with flat plate and cultivated under $30^{\circ} \mathrm{C}$ and $180 \mathrm{rpm}$ for $15 \mathrm{~h}$, and then sent to fermentation culture media to be cultivated for $24 \mathrm{~h}$. Centrifuge the cell for spare after fermentation.

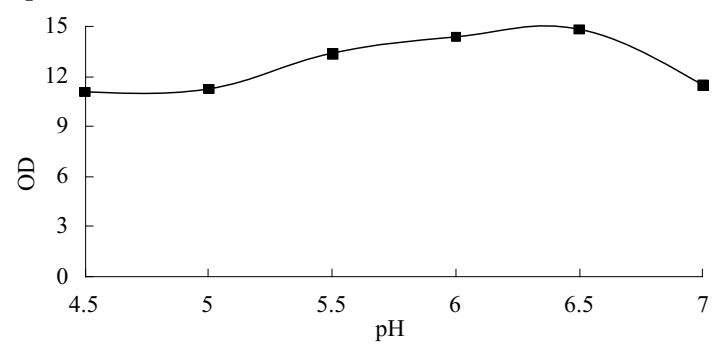

Figure 4. The OD value about cell under different $\mathrm{pH}$ value

\section{ENZYMATIC REDUCTION OF N-BOC-3-PIPERIDONE}

\subsection{Components of reaction solvent}

As for enzymatic reduction of N-Boc-3-piperidone, this article mainly conducts relevant research on the selection of reaction solvent. The components of reaction solvent are to be first explored and confirmed.

a. In $\mathrm{pH}=6.5$ phosphate buffer, methanol co-solvent, adding $5 \%$ glucose to reaction system for direct reaction. 
MATEC Web of Conferences

\begin{tabular}{|c|c|c|c|c|c|c|c|}
\hline Entry & Sol. & Co-sol. & Glucose \% & Final $\mathrm{pH}$ & Yield\% & ee $\%$ & Conf. \\
\hline $\mathrm{a}$ & PBS & $\mathrm{CH}_{3} \mathrm{OH}$ & 5 & 5.5 & 62.3 & 99 & $\mathrm{~S}$ \\
\hline $\mathrm{b}$ & PBS & $\mathrm{CH}_{3} \mathrm{OH}$ & 0 & 6.5 & 70.8 & 99 & $\mathrm{~S}$ \\
\hline $\mathrm{c}$ & PBS & $\mathrm{CH}_{3} \mathrm{OH}$ & 5 & 6.0 & 71.1 & 99 & $\mathrm{~S}$ \\
\hline d & PBS & $\mathrm{CH}_{3} \mathrm{OH}$ & 10 & 6.0 & 70.9 & 99 & $\mathrm{~S}$ \\
\hline $\mathrm{e}$ & A & $\mathrm{CH}_{3} \mathrm{OH}$ & 0 & 6.5 & 68.3 & 99 & $\mathrm{~S}$ \\
\hline $\mathrm{f}$ & $\mathrm{B}$ & $\mathrm{CH}_{3} \mathrm{OH}$ & 0 & 7.0 & 68.1 & 99 & $\mathrm{~S}$ \\
\hline $\mathrm{g}$ & PBS & IPA & 5 & 6.0 & 66.7 & 99 & $\mathrm{~S}$ \\
\hline
\end{tabular}

b. In $\mathrm{pH}=7.0$ phosphate buffer solution, methanol co-solvent, without adding any glucose to reaction system for direct reaction.

c. In $\mathrm{pH}=7.0$ phosphate buffer, methanol co-solvent, adding 5\% glucose to reaction system for reaction.

d. In $\mathrm{pH}=7.0$ phosphate buffer, methanol co-solvent, adding $10 \%$ glucose to reaction system for reaction.

e. Take the culture media diluted for 5 times as the reaction solution for direct reaction $\mathrm{A}$.

f. Take the culture media diluted for 10 times as the reaction solution for direct reaction $\mathrm{B}$.

g. In $\mathrm{pH}=7.0$ phosphate buffer, isopropanol co-solvent, adding 5\% glucose to reaction system for reaction.

As shown in the data of following Table 1, the biocatalyst has an extremely high corresponding selectivity, and its reaction speed becomes very high in the previous three hours before decreasing and even coming to a halt. All the reaction time in the following table are $9 \mathrm{~h}$. In the experiment, all the asymmetrically reduced N-Boc-3-piperidines in the solvents will obtain (S)-N-Boc-3-piperidrol with very high optical purity ee value (ee>99\%), but the yield does not reach $100 \%$. But it is known from comparing the experiment, the phosphate reaction system with glucose has a higher yield than that without glucose, which is because the added glucose fully complements the co-enzyme renewable cycling system in the cell and enables it to keep a relatively high enzyme activity. Whereas increasing the concentration of glucose does not have any obvious facilitation effect on the reaction (comparing the experiment a and d). By comparing the reaction solvent $\mathrm{PBS}$ and $\mathrm{A}, \mathrm{B}$, we know this biological reduction reaction still tends to be suitable for conduction in PBS. As shown in the data of experiment $\mathrm{c}$ and $\mathrm{g}$, the methanol co-solvent has a better effect than isopropanol. So in the phosphate solvent with $5 \%$ of glucose and initial $\mathrm{pH}=7.0$, and in the reaction system with $5 \%$ methanol co-solvent, the maximum conversion rate $71.1 \%$ will be finally obtained.

\subsection{Selection of $p H$ value in the reaction process}

It is known from the experiment about contents in reaction solvent in the Table 1 above that, it has a better effect in the phosphate solvent with initial $\mathrm{pH}=7.0$, so we conduct research on adjusting $\mathrm{pH}$ value to initial $\mathrm{pH}$ value in the reaction process.

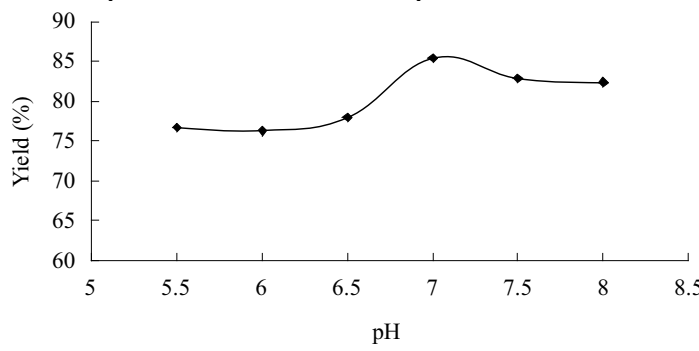

Figure 5. Effect of $\mathrm{pH}$ value of reaction system on the biocatalytic reduction

As shown in Figure 5, we can obviously improve the yield of this biological reduction reaction by controlling the $\mathrm{pH}$ value of reaction solution. As the $\mathrm{pH}$ value is controlled to $5.5,6.0,6.5,7.0,7.5$ and 8.0, the yield will be increased; as it becomes 7.0, the yield for $9 \mathrm{~h}$ hits the maximum $85.4 \%$, whereas the yield starts to decline when $\mathrm{pH}$ value continues to grow.

\section{CONCLUSION}

In this paper, we mainly research the growth enzyme of pichia pastoris and the way of carbonyl reductase in microbial cell, as a biocatalyst, to asymmetrically reduce N-Boc-3-piperidone to obtain the chiral (S)-N-Boc-3-piperidrol by enzyme method. Explore an efficient method with high yield to prepare the biocatalyst by studying the fermentation optimization of pichia pastoris in table turning speed, fermentation time and fermentation liquid $\mathrm{pH}$, and use this biocatalyst to biologically catalyze and reduce 
N-Boc-3-piperidone. It focuses on the effect of this reaction system on the whole reaction. In the experimental research above, the phosphate solvent with 5\% glucose and 5\% methanol co-solvent, as well as $\mathrm{pH}$ value controlled at 7.0 in the reaction process will have a yield rate of $85.4 \%$, and optical purity value hits over $99 \%$. Compared to the state before optimization, the yield is increased by $23.1 \%$, and the optical purity value keeps above $99 \%$. In this asymmetrical reduction reaction by enzyme method, the possible loss of enzyme activity is the main reason for incomplete reaction. To solve this problem, there are many issues that deserve to be studied. Meanwhile we may also find out the genetic sequence against the efficient enzyme of this reaction biocatalyst, and reform the wild bacteria into recombined bacteria to solve the loss of enzyme activity, and thus to realize the asymmetrical reduction reaction by enzyme method in order to finally achieve the goal of high productivity and efficiency and lay a solid foundation for future realization of industrialization.

\section{ACKNOWLEDGEMENT}

This work was supported by National Natural Science Foundation (No. 21303105), the Shanghai Committee of Science and Technology (No. 13430503400), the Science Foundation of Shanghai Institute of Technology (YJ2010-04), the Scientific Research Foundation for the Returned Overseas Chinese Scholars, State Education Ministry (No. ZX2012-05) and Innovation Program of Shanghai Municipal Education Commission (No. 11YZ227).

\section{REFERENCES}

[1] Watson P.S., Jiang B. \& Scott B. 2000. A diastereoselective synthesis of 2, 4-disubstituted piperidines: scaffolds for drug discovery. Org. Lett. 2(23): 3679-3681.

[2] Goss P.E., Baker M.A. \& Carver J.P., et al. 1995. Inhibitors of carbohydrate processing: A new Class of anticancer agents. Clin. Cancer Res., 1(19): 935-944.

[3] XIUO X YI, NGU K. \& CHOA C, et a1. 1997. Selective solid phase synthesis of ureas and hydantoins from common phenyl Carbamate intermediates. Org. Chem., 62(20): 6968-6973.

[4] Merrifield R B. 1964. Solid phase peptide snythesis. II. The synthesis of bradykinin. J. Am. Chem. Osc., 86(2): 304-305.

[5] Liao, R. \& Zhou, Q.Y. Research on the synthesis of N-Boc-piperidines-3-acetic acid. Journal of Southwest University for Nationalities (Natural Science Edition).

[6] Schmid A, Dordick JS. \& Hauer B, et al. 2001. Industrial biocatalysis today and tomorrow. Nature, 409: 258-268.

[7] Tao J. \& Xu J.H. 2009. Biocatalysis in development of green pharmaceutical processes. Curr. Opin. Chem. Biol. 13: 43-50.
[8] Woodley JM. 2008. New opportunities for biocatalysis: making pharmaceutical processes greener. Trends in Biotechnology, 26: 321-327.

[9] Annemarie H, Danielle GIP. \& Jim A. 2001. Asymmetric reduction of ketones via whole cell bioconversions and transfer hydrogenation: Complementary approaches. Tetrahedron Asymmetry, 12: $1025-1034$.

[10] Matsuyama A, Yamamoto H. \& Kawada N. 2001. Industrial Production of (R)-1,3-butanediol by New Biocatalysts J. Mol. Catal. B: Enzym. 11: 513-518.

[11]Liese A, Seelbach K. \& Wandrey C. 2006. Industrial bio transformations. Weinheim: Wiley-VCH. 